\title{
Biodiversity and influence of climatic factors on mosquitoes (Diptera: Culicidae) around the Peixe Angical hydroelectric scheme in the state of Tocantins, Brazil
}

\author{
Júlia dos Santos Silva ${ }^{1,2}{ }^{+}$, Juliana Barreto Pachecoํ, Jeronimo Alencar ${ }^{1}$, Anthony Érico Guimarães ${ }^{1}$ \\ ${ }^{1}$ Laboratório de Diptera, Instituto Oswaldo Cruz-Fiocruz, Av. Brasil 4365, 21045-900 Rio de Janeiro, RJ, Brasil ² Programa de Pós-Gradua- \\ ção em Zoologia, Museu Nacional, Universidade Federal do Rio de Janeiro, Rio de Janeiro, RJ, Brasil
}

The influence of climatic factors on the seasonal frequency of mosquitoes (Diptera: Culicidae) at the Peixe Angical hydroelectric scheme (Tocantins, Brazil) was evaluated in the present paper. Mosquito surveys were conducted in the municipality of Peixe and in areas surrounding the reservoir in the municipalities of Paranã and São Salvador do Tocantins during two daytime periods (10 am-12 noon and $2 \mathrm{pm}-4 \mathrm{pm})$ and two night-time periods $(6 \mathrm{pm}-8 \mathrm{pm}$ and $6 \mathrm{pm}-10 \mathrm{am}$ ) over 14 months. In total, 10,840 specimens from 42 species were captured, $84.5 \%$ of which belonged to the Culcinae. The most common species were Anopheles darlingi, Psorophora albipes and Sabethes chloropterus. The number of Culicidae specimens was higher in months with higher rainfall and air humidity than during the drier months. The large population of Ps. albipes and the presence of both An. darlingi (primary vector for human malaria parasites) and Haemagogus janthinomys (primary vector for yellow fever virus) are highlighted.

Key words: Culicidae - vector ecology - climatic factors - dams

Studies on culicid fauna become increasingly important in areas where human activities have induced environmental changes, as the population dynamics of mosquito vectors may shift in response to altered habitats. Certain species may actually benefit from such changes, thereby increasing their density and presenting a threat to human health. The construction of hydroelectric power stations offers a prime example of this type of human intervention. This process often results in numerous changes to the surrounding environment, especially when it involves flooding of land adjacent to rivers and modification of river flow regimes (Bastos \& Saito 2000).

According to Tauil (1986), the implementation of large construction projects attracts a large number of people and directly affects the physical and biotic environment, thus producing an epidemiological risk factor. The Peixe Angical hydroelectric scheme (PAHS) on the Tocantins River in the state of Tocantins (TO), Brazil has revived the discussion about the extent of environmental changes that follow such large-scale projects. It is critical that we improve our understanding of the transformations caused by human activities that alter the environment and the population dynamics of insect vectors.

In the present paper, we report the seasonal frequency of the mosquito fauna before and during the filling of the PAHS reservoir as well as the possible influences exerted by climatic factors.

Financial support: ENERPEIXE SA

+ Corresponding author: juliass@ioc.fiocruz.br

Received 4 August 2009

Accepted 5 March 2010

\section{MATERIALS AND METHODS}

PAHS is located on the Tocantins River in the municipality of Peixe (TO). The dam is $6.2 \mathrm{~km}$ long and $39 \mathrm{~m}$ in height. The area of the reservoir is $294 \mathrm{~km}^{2}$ and the spillway width is $213 \mathrm{~m}$, with an outflow capacity of 37.044 $\mathrm{m}^{3} / \mathrm{s}$. Construction of PAHS started in April 2002. The filling of the reservoir began on January 142006 and concluded on April 22 2006. On June 27 of the same year, commercial operation of Generating Unit 1 began. The environmental changes resulting from PAHS during this period included intense and extensive deforestation, partial obstruction of rivers and creeks, accumulation of water and the formation of large manmade lakes.

Because TO is in a transition area, it presents climatic and physical characteristics of both the Amazon Region, which is wet for most of the year and is covered with tropical rainforest and the Central Region of Brazil, which has a drier climate and vegetation dominated by cerrado, which covers $87.8 \%$ of the state's area (Fig. 1). The cerrado terrain occupies depressions over the majority of the territory. Plateau areas showing significant erosion can be found in the southern and northeastern regions, while extensive lowlands predominate in the central part of the state. The Tocantins River basin comprises approximately two-thirds of the state's hydrographic basin; the Araguaia River makes up the remainder, with several important sub-basins. The Araguaia, Tocantins, Sono, Balsas and Paranã are the most important rivers in the state.

The climate in the PAHS region is tropical, with mean annual temperatures of $26^{\circ} \mathrm{C}$ in the rainy months (OctoberMarch) and $32^{\circ} \mathrm{C}$ in the dry season (April-September). The mean annual rainfall is $1.800 \mathrm{~mm}$ in the northern and eastern regions of the state and $1.000 \mathrm{~mm}$ in the southern region.

This study was carried out in the municipality of Peixe, the location of the main construction site and in areas adjacent to the reservoir in the municipalities of Paranã and 


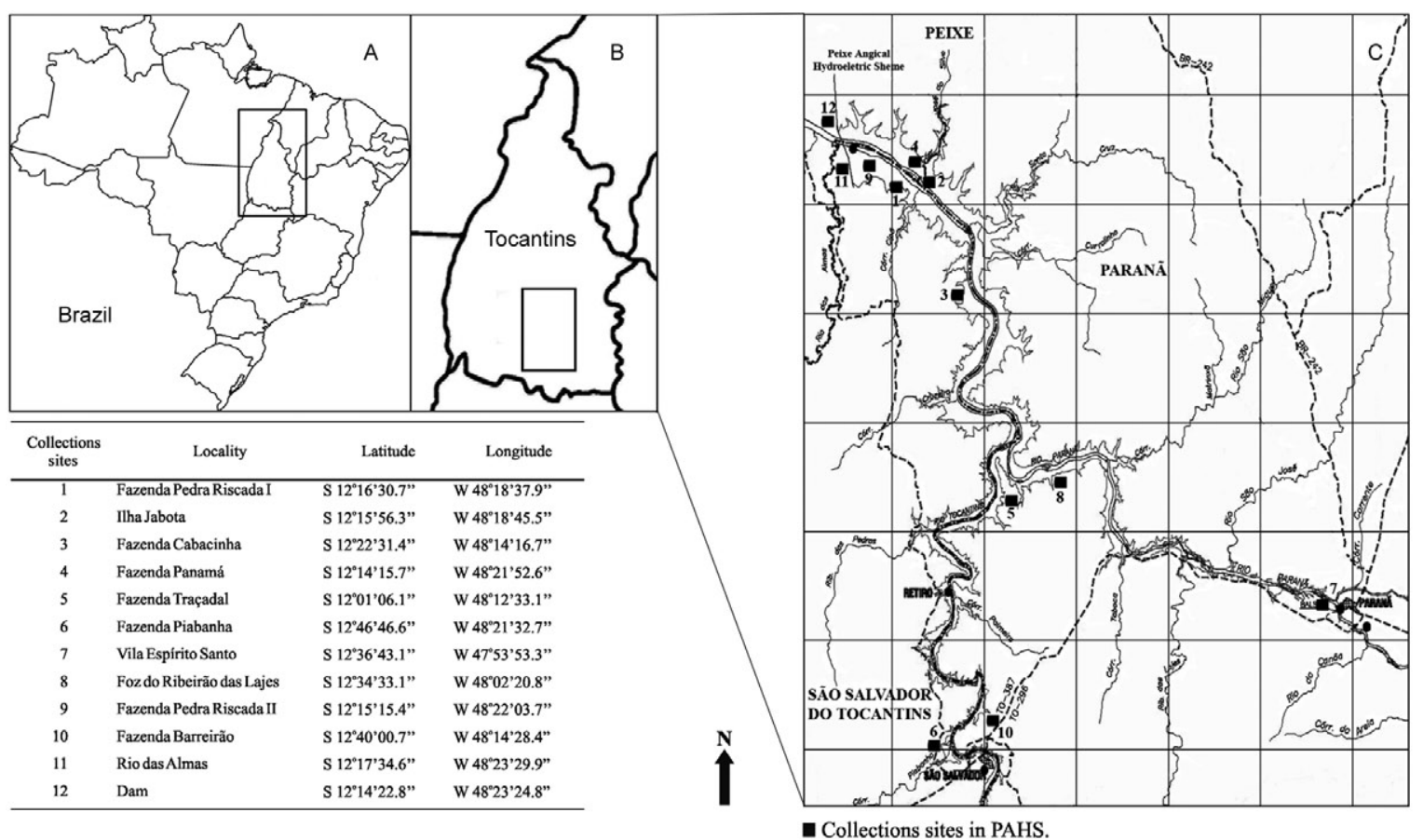

Fig. 1: location of the Peixe Angical hydroelectric scheme reservoir in Brazil (A), in detail in the state of Tocantins (B); map showing the three areas under direct influence of the reservoir, highlighting the specimen capture points (C).

São Salvador do Tocantins. Twelve collection sites were established. They were distributed between these three areas and were directly influenced by the reservoir, as indicated in Fig. 1.

Peixe - The municipality of Peixe covers a territorial area of $5,291.18 \mathrm{~km}^{2}$ at an altitude of $240 \mathrm{~m}$. Peixe is located on the left bank of the Tocantins River at the southern extremity of the central part of the state. The samplings were carried out along the banks of the Tocantins River, close to the dam that forms the PAHS reservoir. There was a large flow of people through this area because of the dam construction. The collection sites placed at this locality were 1, 2, 3, 4, 9, 11 and 12 (Fig. 1).

Paranã - The municipality of Paranã covers a territorial area of $11,260.15 \mathrm{~km}^{2}$ at an altitude of $274 \mathrm{~m}$. Paranã is located at the southern extremity of the state. Sampling was performed close to the banks of the Paranã River, in riparian areas where typical cerrado vegetation can be found. The capture points placed at this locality were 5, 7 and 8 (Fig. 1).

São Salvador do Tocantins - This municipality covers a territorial area of $1,422.03 \mathrm{~km}^{2}$ at an altitude of $120 \mathrm{~m}$. São Salvador do Tocantins is located in the southern part of the state. This municipality has typical cerrado vegetation with mountains and lowlands. The sampling was carried out on the banks of streams that empty into the reservoir, where the vegetation forms a dense forest. The capture points placed at this locality were 6 and 10 (Fig. 1).

Sampling was performed every two months for five consecutive days between February 2004-April 2006. Collections were carried out during four defined periods, i.e., from 10 am- 12 pm, 2 pm- 4 pm, 6 pm- 8 pm and 6 pm-10 am. Members of the Diptera Laboratory [Instituto Oswaldo Cruz (IOC)] collected mosquitoes resting on vegetation and any specimen that was likely to have been attracted by the presence of humans. For the night collections, Shannon traps (Forattini 2002) with a 100 -watt universal light were used and insects were captured while resting on the walls. Samplings were also performed using traps (Lard Can Trap) with animal bait (Gallus g. domesticus). The traps were installed at the tops of trees, about $7 \mathrm{~m}$ above ground level. Temperature and relative air humidity were recorded using a thermohygrometre (Oregon Scientific, model RMR132HG), which was placed $1 \mathrm{~m}$ above ground level. Daily rainfall data were obtained from the Instituto Nacional de Meteorologia (INMET). Mosquitoes were taken to the laboratory, identified and deposited in the Entomological Collection of IOC under the title "PAHS collection" (Coleção de AHE-Peixe). Identifications were conducted using the adult identification keys of Lane (1953a, b), Consoli and Lourenço-de-Oliveira (1994), Forattini (2002) and Harbach and Howard (2009). The genus and sub-genus abbreviations followed Reinert (2001).

Graphical representations and analyses were performed for the species that occurred at frequencies greater than $5 \%$, with respect to each subfamily/tribe within each type of analysis. The data obtained from the sum of all mosquitoes from all captures in the three areas were expressed as absolute values and percentages and transformed into Williams means (Haddow 1960). The confidence interval was 95\%. The influence of climatic factors on the culicid fauna was analysed using linear correlation coefficients with a confidence limit of $90 \%$ for $r=0.458$. 


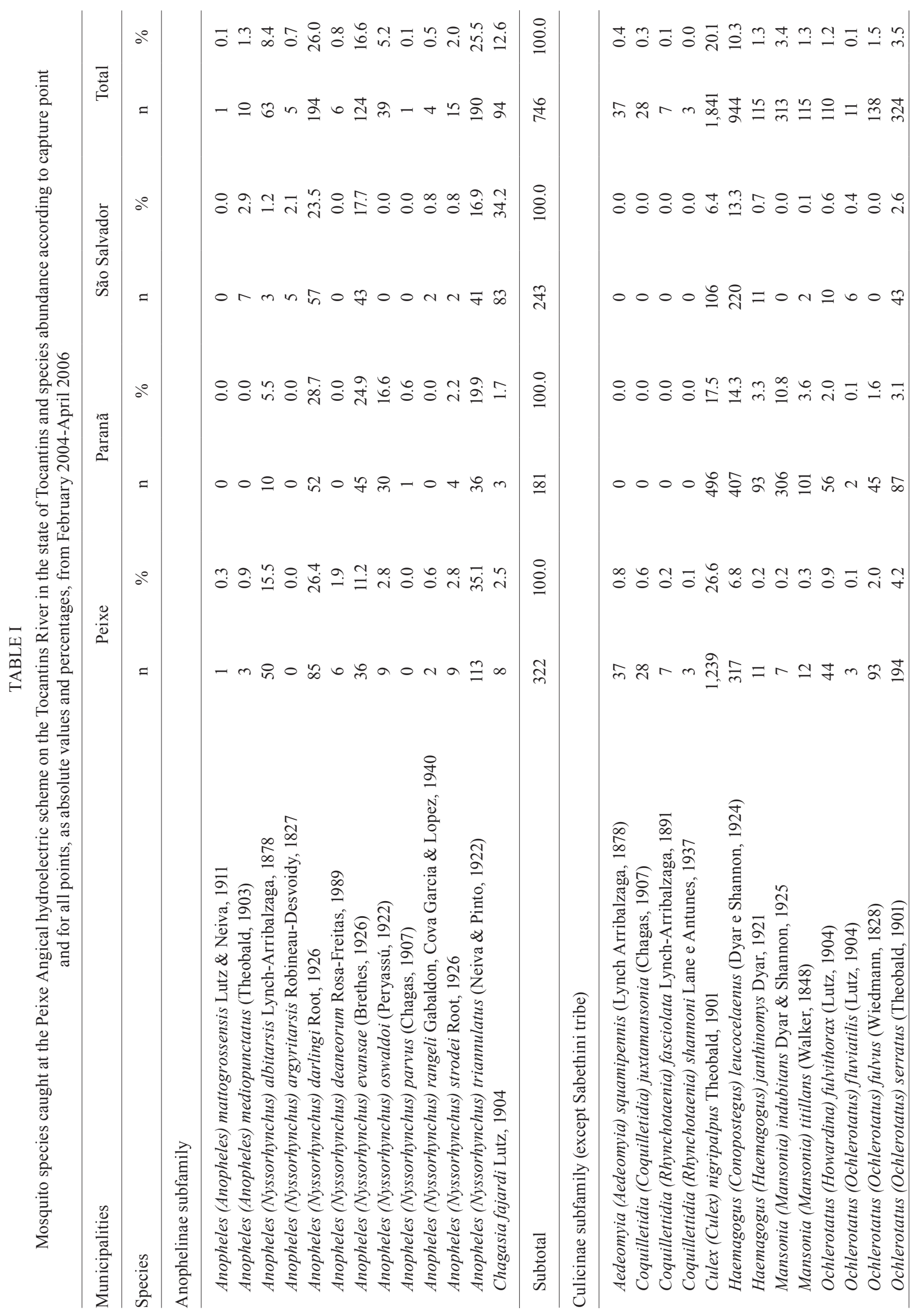




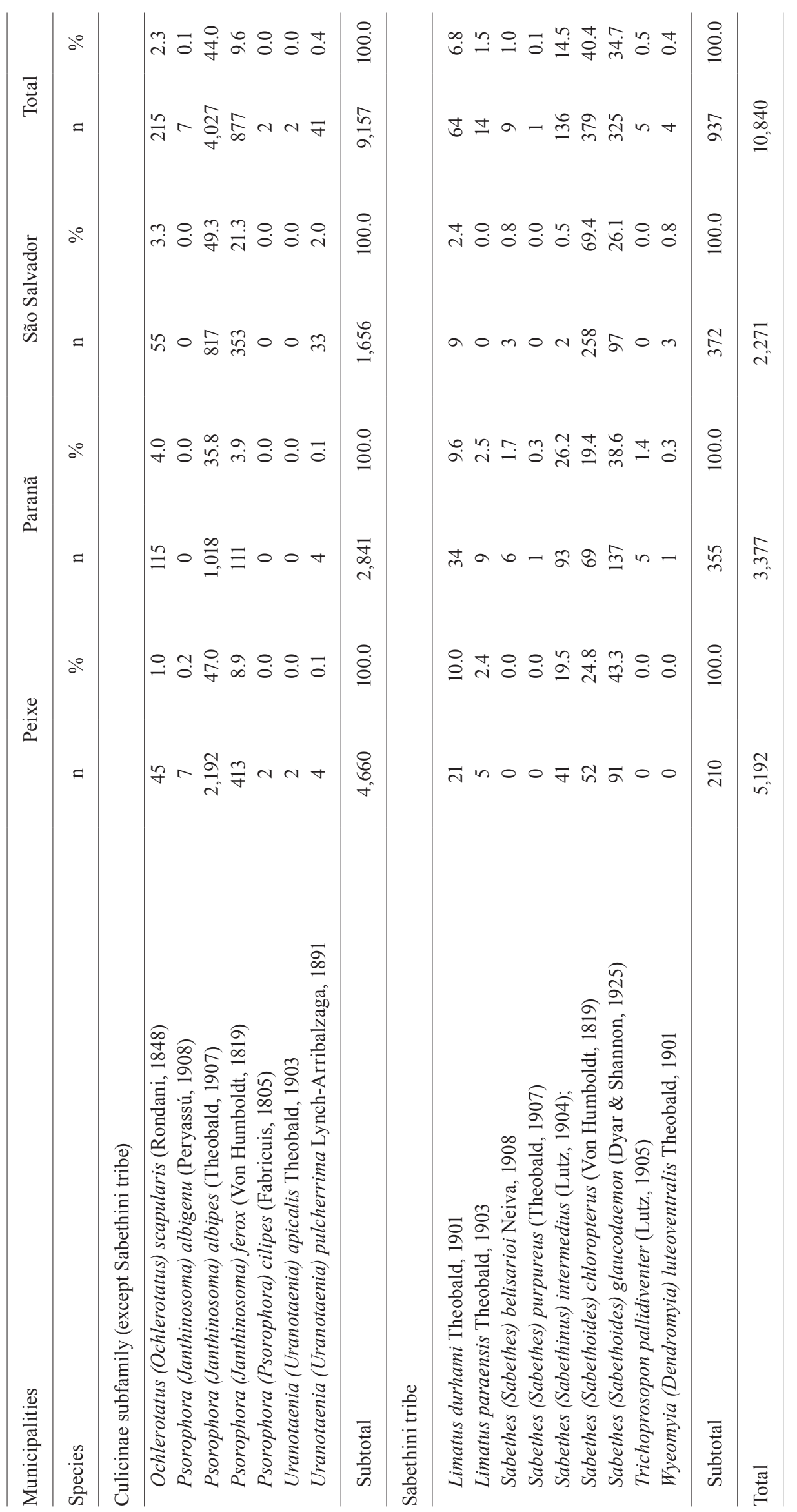




\section{RESULTS}

Over the course of the two-year survey, 10,840 specimens of two subfamilies, 14 genera and 42 species were caught (Table I). The Culicinae were the most numerous, accounting for $93.1 \%$ of the specimens caught, while the Anophelinae accounted for $6.9 \%$. Psorophora albipes was the most numerous species, accounting for $37.1 \%$ of the specimens caught among all sampling points (Table I).

According to data from INMET, the months with higher rainfall spanned December-March, while the drought period lasted from May-October during the two years of the study (Fig. 2A). Each year, the highest temperatures were recorded between October-February (Fig. 2B), while the period between December-April presented the highest relative air humidity (Fig. 2C).

The mosquito fauna presented a sizeable number of specimens in February, followed by a large increase in April and a decline in June and August. In October, the number of specimens began to increase again (Fig. 3A).

The Anophelinae were favoured in April and mainly in June and October, when the population curve was above the confidence interval. The least favourable period was from December-February (Fig. 3B). Populations of Anopheles albitarsis and Anopheles evansae peaked above the expected interval in October (Fig. 3C, E). Anopheles darlingi showed its greatest population increase in April (Fig. 3D) and Anopheles oswaldoi in April and June (Fig. 3F). Anopheles triannulatus showed its greatest population increase in June and October (Fig. 3G). Lastly, Chagasia fajardi presented its greatest population increase in June (Fig. 3H). For all anophelines, the period between December-February yielded the lowest number of specimens (Fig. 3B-H).

For the representatives of the Culicinae (except for the Sabethini), the period between December-April was the most favourable, while the lowest abundances were recorded between June-October (Fig. 3I). Haemagogus janthinomys, Ps. albipes and Psorophora ferox were most abundant between December-April and at their lowest levels between June-October (Fig. 3 K-M). Culex nigripalpus had the lowest number of specimens in August and the highest in October (Fig. 3J).

The Sabethini were very abundant between December-April but infrequent between June-August (Fig. 3N). Limatus durhami and Sabethes chloropterus presented numbers of specimens above the confidence interval in December and below it in June and August (Fig. 3O, P). Sabethes glaucodaemon and Sabethes intermedius were most abundant in February (Fig. 3Q, R).

To determine the influence of climatic factors on culicid fauna in the region and understand the existence of population peaks outside the confidence interval, the significance of these interrelations was analysed using linear correlation coefficients. Absolute values of mosquitoes captured manually or in Shannon or animal bait traps over the 14 months of the study were analysed according to the capture area (municipalities of Peixe, Paranã and São Salvador) (Table II). The abundance of An. albitarsis s.l. was positively correlated with temperature in the three areas, while this variable had a nega- tive influence on Ch. fajardi in São Salvador (Table II). A correlation based on relative humidity variations was detected for seven species. For Cx. nigripalpus (Peixe), Hg. janthinomys (São Salvador), Ps. albipes (São Salvador), PS. ferox (Peixe and São Salvador) and Sa. glaucodaemon (Peixe), this was a positive correlation, such that increases in relative humidity were associated with increased numbers of specimens collected. For An. albitarsis s.l. and An. triannulatus in Peixe, relative humidity had a negative influence. $\mathrm{Hg}$. janthinomys (Peixe and São Salvador), Li. durhami (São Salvador), Ps. ferox (Paranã), Sa. glaucodaemon (Peixe) and Sa. intermedius (Peixe) were positively influenced by rainfall (Table II).

\section{DISCUSSION}

Several species belonging to the Anophelinae are known to use large lakes as larval habitat (Forattini 2002) and therefore comprise the group most likely to benefit

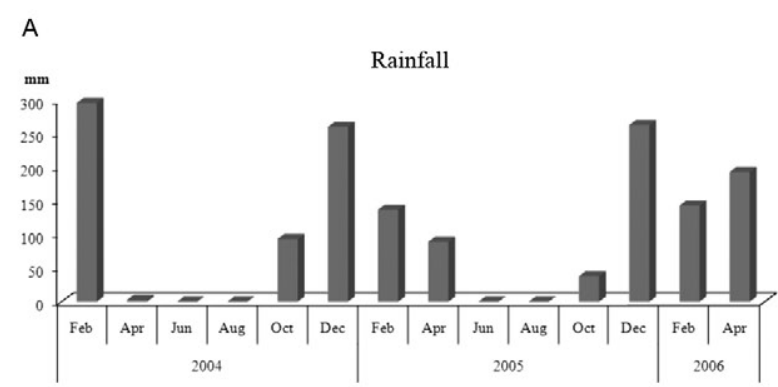

B

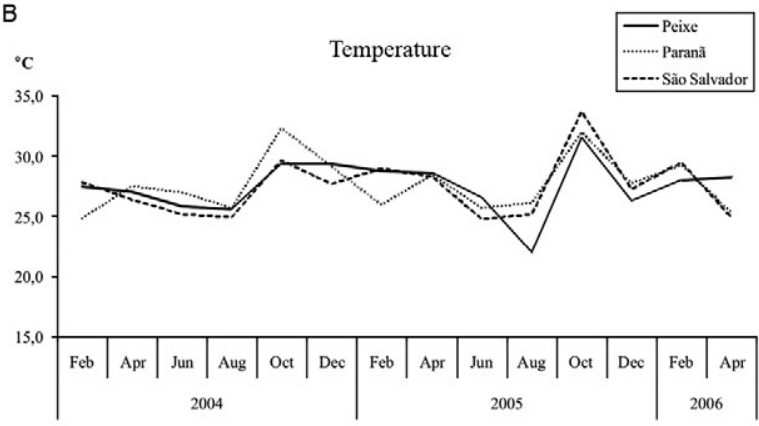

C

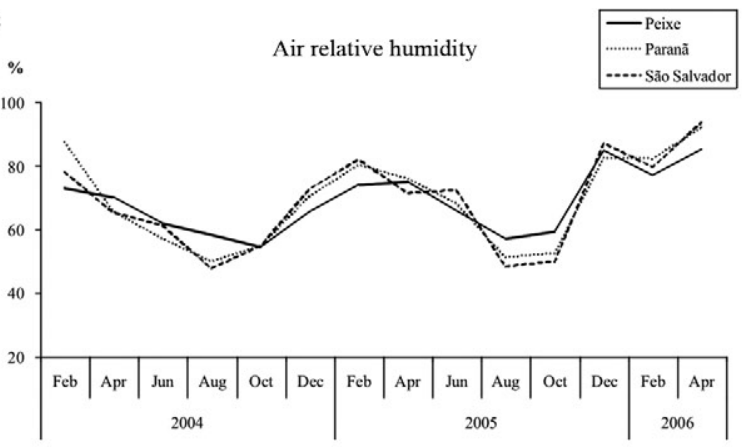

Fig. 2: climatic data relating to accumulated monthly rainfall (A), temperature (B) and relative air humidity (C) for the region around the Peixe Angical hydroelectric scheme on the Tocantins River in the state of Tocantins. 

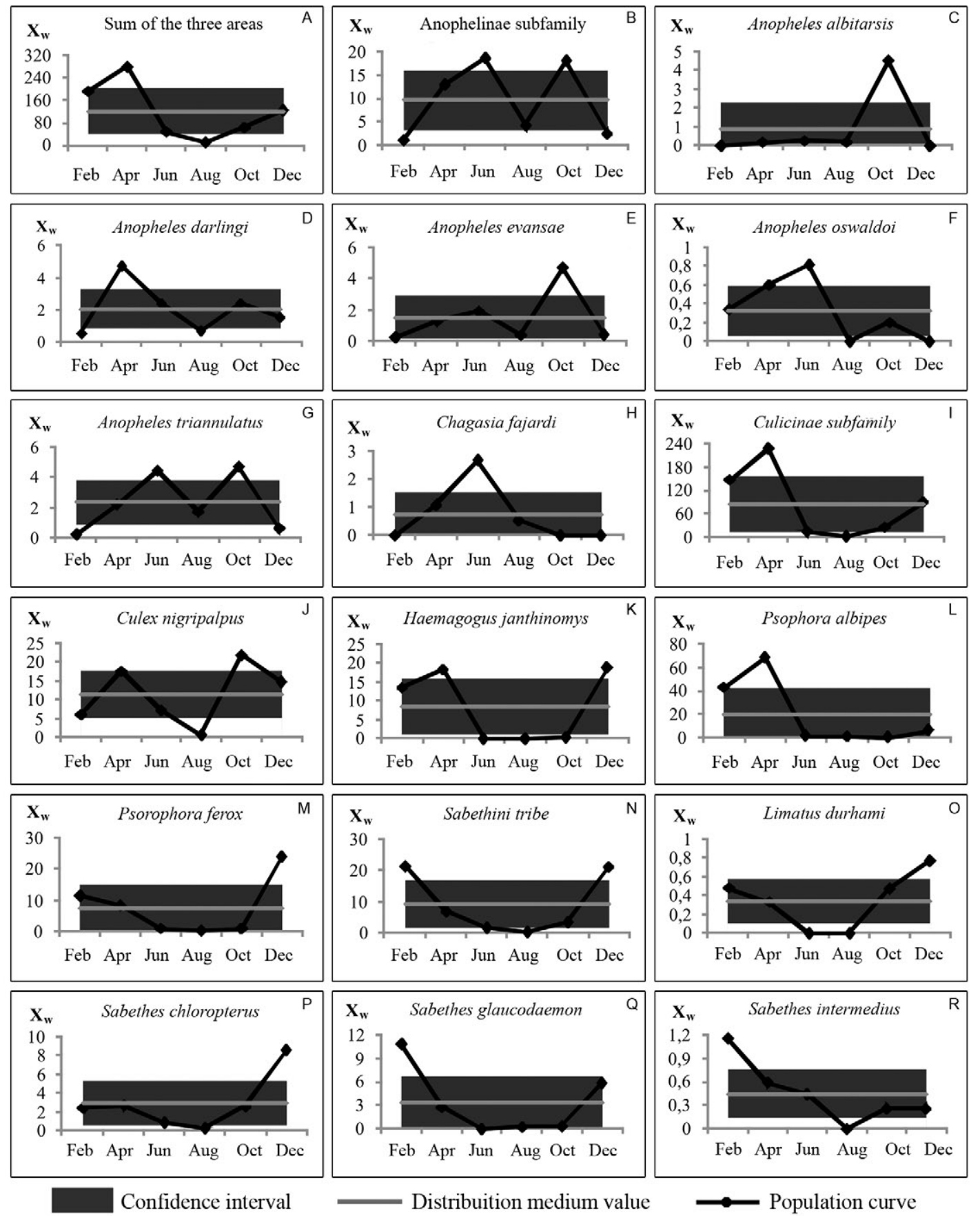

Fig. 3: seasonal frequency of mosquito species, according of Williams means $\left(\mathrm{X}_{\mathrm{w}}\right)$ around the Peixe Angical hydroelectric scheme on the Tocantins River in the state of Tocantins from February 2004-April 2006.

from the formation of hydroelectric reservoirs. However, the mosquito vectors that transmit malaria (MS 2003) and sylvatic yellow fever (Vasconcelos 2003) (transmitted by Haemagogus mosquitoes) are both endemic to the region of the present study and other arboviruses can also be transmitted by Culicidae vectors that occur in this region. We therefore chose to perform captures during both day and night so that we could collect data for the anopheline fauna as well as other epidemiologically important species.
The seasonal frequency of most species indicated that there was a relationship between culicid occurrence and particular aspects of the regional climate. Some authors have observed that the availability of larval habitats (Hayes \& Charlwood 1979, Guimarães et al. 2000) and the abundance of mosquitoes are mainly controlled by rainfall (Guimarães et al. 2001), even in artificially altered environments (Forattini et al. 1996) like PAHS. Montes (2005) reported that among the climatic factors analysed, temperature was most highly correlated with 


\section{TABLE II}

Linear correlation coefficient (r) between culicid abundance in the three localities of Peixe Angical hydroelectric scheme on the Tocantins River in the state of Tocantins and temperature, relative air humidity (RAH) and rainfall for February 2004-April 2006

\begin{tabular}{|c|c|c|c|c|c|c|c|c|c|}
\hline \multirow{2}{*}{$\begin{array}{l}\text { Municipalities } \\
\text { Species }\end{array}$} & \multicolumn{3}{|c|}{ Peixe } & \multicolumn{3}{|c|}{ Paranã } & \multicolumn{3}{|c|}{ São Salvador } \\
\hline & Temperature & $\mathrm{RAH}$ & Rain & Temperature & $\mathrm{RAH}$ & Rain & Temperature & RAH & Rain \\
\hline \multicolumn{10}{|l|}{ Anophelinae subfamily } \\
\hline Anopheles albitarsis & 0.54 & -0.52 & -0.19 & 0.46 & -0.43 & -0.25 & 0.57 & -0.41 & -0.08 \\
\hline Anopheles darlingi & 0.32 & 0.17 & -0.08 & -0.28 & -0.18 & -0.38 & -0.21 & 0.44 & 0.30 \\
\hline Anopheles evansae & 0.42 & -0.13 & -0.22 & 0.45 & -0.39 & -0.36 & 0.06 & -0.29 & -0.09 \\
\hline Anopheles oswaldoi & -0.04 & 0.02 & -0.33 & -0.21 & 0.15 & 0.11 & 0.00 & 0.00 & 0.00 \\
\hline Anopheles triannulatus & 0.41 & -0.49 & -0.40 & -0.21 & -0.43 & -0.52 & 0.04 & -0.40 & -0.38 \\
\hline Chagasia fajardi & -0.21 & -0.19 & -0.28 & -0.08 & -0.24 & -0.28 & -0.52 & 0.18 & -0.18 \\
\hline \multicolumn{10}{|c|}{ Culicinae subfamily (except Sabethini) } \\
\hline Culex nigripalpus & 0.30 & 0.55 & 0.26 & 0.13 & 0.31 & 0.22 & -0.10 & 0.12 & -0.18 \\
\hline Haemagogus janthinomys & 0.25 & 0.34 & 0.51 & -0.20 & 0.21 & 0.11 & -0.02 & 0.75 & 0.54 \\
\hline Psorophora albipes & 0.24 & 0.29 & 0.13 & -0.28 & 0.35 & 0.10 & 0.00 & 0.57 & 0.31 \\
\hline Psorophora ferox & 0.15 & 0.62 & 0.42 & 0.03 & 0.37 & 0.48 & -0.18 & 0.75 & 0.40 \\
\hline \multicolumn{10}{|l|}{ Sabethini tribe } \\
\hline Limatus durhamii & 0.41 & 0.23 & 0.07 & 0.19 & 0.28 & 0.12 & -0.02 & 0.38 & 0.52 \\
\hline Sabethes chloropterus & 0.41 & 0.24 & 0.32 & 0.42 & -0.03 & 0.18 & 0.24 & 0.25 & 0.24 \\
\hline Sabethes glaucodaemon & 0.08 & 0.52 & 0.61 & -0.17 & 0.20 & 0.08 & 0.27 & 0.47 & 0.31 \\
\hline Sabethes intermedius & 0.01 & 0.13 & 0.49 & -0.10 & 0.03 & -0.10 & -0.25 & -0.14 & -0.28 \\
\hline
\end{tabular}

two-tailed tests with confidence limit of $90 \%$ for the critical value of $r=0,458\left(\mathrm{r}_{0.1(2) 12}=0.458\right)$.

the number of individuals caught in the study area of Serra da Cantareira (state of São Paulo). In addition, this study reported that larval development was also influenced by rainfall and the temperature of the 10 days prior to capture (Forattini 2002).

In the present paper, the highest number of $A n$. darlingi specimens was recorded in April 2006, when the PAHS reservoir was being filled. This process was accompanied by greater shading of the banks and increased quantities of organic matter produced from the decomposition of vegetation submerged around the edges. Some reports have suggested that in areas around hydroelectric schemes, the water level in the reservoir is the determining factor for anopheline populations; climatic factors are reduced to a secondary influence (Guimarães et al. 2004, Paula \& Gomes 2007). Moreover, in the case of anophelines, we must take into account the elevated water levels in the Tocantins and Paranã Rivers and their tributaries during the months of high rainfall shortly before the filling of the reservoir, as this may have impeded water accumulation on the riverbanks.

Other authors have found that during the periods of greatest rainfall, An. darlingi populations declined because of the unavailability of larval habitats (Pajot et al. 1977, Hayes \& Charlwood 1979). In the present study, this trend was also noted for other anopheline species such as An. albitarsis s.l. and An. triannulatus, as fewer specimens were collected when the Tocantins and Paranã Rivers were at high levels. In addition, An. albitarsis s.l. increased in number when the ambient temperature was higher. Carvalho et al. (2002) reported that temperature influenced the embryonic development of An. albitarsis, showing that egg eclosion was successful at $26^{\circ} \mathrm{C}$ and reduced at a lower temperature $\left(21^{\circ} \mathrm{C}\right)$.

$C h$. fajardi was most abundant during the cooler season. This pattern is related to the fact that the eggs of this species develop more successfully when the water in the larval habitat is clean, cold and flowing (Baerg \& Boreham 1974), which does not occur during the warmer months, as noted by Guimarães et al. (2001).

The Culicinae, including the Sabethini, oscillated according to the rainfall regime of the region because of the higher availability of larval habitats, with increasing numbers of specimens collected during the humid and rainy months. For $C x$. nigripalpus, other authors have found the same temporal distribution (Lourenço-deOliveira et al. 1985, Guimarães et al. 2000, 2001); the correlation with humidity helps to explain why it is favoured during the wetter months. In the present study, Hg. janthinomys was more abundant in the rainiest and humid months, also because of the availability of larval habitats. Trapido and Galindo (1957) reported catching Haema- 
gogus mainly during the rainiest months and Alencar et al. (2008) also reported increased population density of this species during the hot and humid months. Pinto et al. (2009) found a positive correlation between $\mathrm{Hg}$. janthinomys and air humidity in Caxiuanã National Forest. Ps. albipes acted as an opportunistic species, taking advantage of temporary larval habitats. Ps. ferox also followed this pattern, as noted by Guimarães et al. (2001).

$S a$. chloropterus and Sa. glaucodaemon presented population increases in the humid and rainy months, also because of the higher availability of larval habitats, thus corroborating the observation of Pinto et al. (2009). Likewise, Li. durhami showed population increases in rainy months. Zequi et al. (2005) also reported greater abundances of $L i$. durhami during the summer due to the greater availability of larval habitats and Guimarães et al. (2000) found the greatest incidence of this species in January and April. Guimarães and Arlé (1984) found that $\mathrm{Sa}$. intermedius was most abundant during the hot and rainy season, particularly in January. In the PAHS region, the highest abundance was also recorded during the rainy period.

Hence, our survey reveals that before the reservoir was formed, the mosquito fauna was strongly influenced by the abiotic features of the region, particularly the relative air humidity and rainfall. These factors had a positive influence on Culicinae species found in the area and a negative influence on anophelines. However, while temperature had some influence on anopheline distribution, no such relationship was observed for the Culicinae.

We conclude that in view of the high populations of the species usually implicated in pathogen transmission and the fact that the region around the PAHS reservoir is endemic for malaria (MS 2003) and yellow fever (Vasconcelos 2003), this region is particularly vulnerable to occurrences of these diseases.

\section{REFERENCES}

Alencar JA, N Dégallier, A Hannart, JS Silva, JB Pacheco, AE Guimarães 2008. Circadian and seasonal preferences for hematophagy among Haemagogus capricornii, Hg. janthinomys and Hg. leucocelaenus (Diptera: Culicidae) in different regions of Brazil. $J$ Vec Ecol 33: 389-392.

Baerg DC, MM Boreham 1974. Experimental rearing of Chagasia bathana (Dyar) using induced mating and description of the egg stage. J Med Entomol 11: 631-632.

Bastos FP, Saito CH 2000. Abordagem energética na educação ambiental. ADVIR 13: 11-19.

Carvalho SCG de, Junior AJM, Lima JBP, Vale D 2002. Temperature influence on embryonic development of Anopheles albitarsis and Anopheles aquasalis. Mem Inst Oswaldo Cruz 97: 1117-1120.

Consoli RAGB, Lourenço-de-Oliveira R 1994. Principais mosquitos de importância sanitária no Brasil, Editora Fiocruz, Rio de Janeiro, 225 pp.

Forattini OP 2002. Culicidologia médica: identificação, biologia, epidemiologia, Vol. II, Editora da Universidade de São Paulo, São Paulo, 860 pp.

Forattini OP, Kakitani I, Massad E, Marucci D 1996. Studies on mosquitoes (Diptera: Culicidae) and anthropic environment. 11. Biting activity and blood-seeking parity of Anopheles (Kerteszia) in South-Eastern Brazil. Rev Saude Publica 30: 107-114.
Guimarães AE, Arlé M 1984. Mosquitos no Parque Nacional da Serra dos Órgãos, estado do Rio de Janeiro, Brasil. I. Distribuição estacional. Mem Inst Oswaldo Cruz 79: 309-323.

Guimarães AE, Gentile C, Alencar J, Lopes CM, Mello RP 2004. Ecology of Anophelinae (Diptera: Culicidae) vectors of malaria in área of Serra da Mesa dam, state of Goiás, Brazil. I. Frequency and climatic factors. Cad Saude Publica 20: 109-118.

Guimarães AE, Gentile C, Lopes CM, Sant'anna A 2001. Ecologia de mosquitos em áreas do Parque Nacional da Serra da Bocaina. II. Freqüência mensal e fatores climáticos. Rev Saude Publica 35: 392-399.

Guimarães AE, Mello RP, Lopes CM, Gentile C 2000. Ecology of mosquitoes (Diptera: Culicidae) in areas of Serra do Mar State Park, state of São Paulo, Brazil. I. Monthly frequency and climatic factors. Mem Inst Oswaldo Cruz 95: 1-16.

Haddow AJ 1960. Studies on the biting-habits and medical importance of eats African mosquitoes in the genus Aedes. I. Subgenera Aedimorphus, Bankisinella and Dunnius. Bull Ent Res 50: 759-779.

Harbach RE, Howard TM 2009. Review of the genus Chagasia (Diptera: Culicidae: Anophelinae). Zootaxa 2210: 1-25.

Hayes J, Charlwood D 1979. Dinâmica estacional de uma população de Anopheles darlingi numa área endêmica de malária no Amazonas. Acta Amazônica 9: 79-86.

Lane J 1953a. Neotropical Culicidae, Vol. I, Editora Universidade de São Paulo, São Paulo, 548 pp.

Lane J 1953b. Neotropical Culicidae, Vol. II, Editora Universidade de São Paulo, São Paulo, 1112 pp.

Lourenço-de-Oliveira R, Silva TF 1985. Alguns aspectos da ecologia dos mosquitos (Diptera: Culicidae) de uma área de planície (Granjas Calábria) em Jacarepaguá, Rio de Janeiro. III. Preferência horária das fêmeas para o hematofagismo. Mem Inst Oswaldo Cruz 80: 195-202.

Montes J 2005. Fauna de Culicidae da Serra da Cantareira, São Paulo, Brasil. Rev Saude Publica 39: 578-584.

MS - Ministério da Saúde Brasil/Secretaria de Vigilância em Saúde 2003. Programa nacional de prevenção e controle da malária: PNCM, Ministério da Saúde, Brasília, 132 pp.

Pajot FX, Le Pont F, Molez JF, Dégallier N 1977. Agressivité d' Anopheles (Nyssorhynchus) darlingi Root, 1926 (Diptera: Culicidae) en Guyne Française. Cah ORSTOM ser Entomol Med Parasitol 15: 15-22.

Paula MB de, Gomes A de C 2007. Culicidae (Diptera) em área sob influência de construção de represa no estado de São Paulo. Rev Saude Publica 41: 284-289.

Pinto CS, UEC Confalonieri, BM Mascarenhas 2009. Ecology of Haemagogus sp. and Sabethes sp. (Diptera: Culicidae) in relation to the microclimates of the Caxiuanã National Forest, Pará Brazil. Mem Inst Oswaldo Cruz 104: 592-598.

Reinert JF 2001. Revised list of abbreviations for genera and subgenera of Culicidae (Diptera) and notes on generic and subgeneric changes. J Am Mosq Control Assoc 171: 51-55.

Tauil PL 1986. O controle da malária na Amazônia. Rev Fund SESP 31: $249-252$.

Trapido H, Galindo P 1957. Mosquitoes associated with sylvan yellow fever near Almirante Panama. Amer J Trop Med Hyg 6: 114-144.

Vasconcelos PFC 2003. Febre amarela. Rev Soc Bras Med Trop 36: 275-293.

Zequi JAC, Lopes J, Medri IM 2005. Imaturos de Culicidae encontrados em recipientes instalados em mata residual no município de Londrina, Paraná, Brasil. Rev Bras Zool 22: 656-661. 